\title{
BIOTECHNOLOGICAL STUDIES ON Solanum viride PLANT: B- IDENTIFICATION OF NEW CLONES THROUGH SOMACLONAL VARIATION OF SolanUm viride PLANT, AND SOLVING THE PROBLEM OF VITRIFICATION.
}

Emara, H. A. 1; I. A. Ibrahim'; M. H. EL-Massry² and A. A. Dahab ${ }^{2}$

${ }^{1}$ Dept. of Plant Biotechnology, Genetic Engineering and Biotechnology Research Institute, Minufiya University, Egypt.

2 Dept. of Medicinal and Aromatic Plants. Horticulture Research Institute. Ministry of Agriculture

\begin{abstract}
Sixteen unvitrified shoots were produced through cell line technique on a recommended media (Emara et al. 2008). These media were, MS medium supplemented with $0.5 \mathrm{mg} / \mathrm{BA}+1.5 \mathrm{mg} / \mathrm{l} \mathrm{NAA}$ for callus formation, and MS medium contained $1.0 \mathrm{mg} / \mathrm{l} \mathrm{BA}$ for callus differentiation. The effect of number of subculture and the clone type on the growth and development of these clones was evaluated by subculturing the sixteen clones for five subcultures on MS medium supplemented with $2.0 \mathrm{mg} / \mathrm{l} \mathrm{BA}$. Subculture number 3 significantly showed the highest shoot number, leaf number and fresh weight/plantlet compared to all other subcultures. Concerning the effect of the clone type, clones number 9 and 10 observed the highest response in the same parameters mentioned above. The obtained plantlets of all clones were successfully acclimatized. However, during the acclimatization, plantlets of clones 11 and 10 showed the highest responses of survival percentage $(95 \%$ and 92.33 , respectively), and clones 9 and 10 observed high responses in the other growth parameters (shoot and leaf number/plantlet and plantlet height). Interestingly, the RAPD analysis of nuclear DNA confirmed that all the sixteen clones were different from the mother plant. Moreover, most of these clones showed some differences between each other. Accordingly, recommendation can be raised as to produce unvitrified plantlets as new clones of green nightshade (Solanum viride Solander ex Forst. f.) through cell line technique.
\end{abstract}

\section{INTRODUCTION}

The family Solanaceae contains several well known cultivated crops such as tomato (Lycopersicon esculentum), eggplant (Solanum melogena), tobacco (Nicotiana tabacum), pepper (Capsicum annuum) and potato (Solanum tuberosum). Within the genus Solanum over a thousand species have been recognized. Green nightshade (Solanum viride Solander ex Forst. f.) is wide spread in warmer regions, it is found growing in different habitats, and it occurs naturally or cultivated and contains solasodine and steroidal alkaloids (Han, 1998). Extracts of glycoalkaloids can be used to obtain a potential skin cancer preparation for clinical research (Nada, et al. 2005). Shoots obtained directly from the explants (leaf segments) during part one of this study (Emara et al. 2008) as direct organogeneses were clearly vitrified which negatively affected the growth and development of these cultures in vitro and acclimatization. Vitrification is a problem which often occurs with in vitro cultures and vitrified shoots are abnormally glassy, thick and translucent 
(Assareh and Hennerty, 1997). Moreover, vitrification is a physiological disorder that can be a serious problem in plant micropropagation. Vitrified microplants lose their ability to propagate due to difficulties in acclimatization (Mohamed, et al. 1992). For this reason, this study was designed as a trial to produce unvitrified plantlets through cell line technique (as indirect organogenesis). The in vitro techniques provide the mechanism to generate large populations for mutation induction, selection and rapid multiplication of the selected mutants.

\section{MATERIALS AND METHODS}

This study was carried out in the Lab. of Biotechnology, Genetic Engineering and Biotechnology Research Institute (GEBRI), Minufiya University, Sadat City, and Lab. of Biotechnology, Horticulture Research Institute, Ministry of Agriculture, Egypt on Solanum viride plant during the period from 2002 to 2007.

\section{Plant Materials:}

Seeds of Solanum viride were obtained from the Genetic Engineering and Biotechnology Research Institute, Minufiya University, Sadat City, Egypt. Mother plant was selected which was normal, healthy grown, free of any disease symptoms. Explants used in tissue culture experiments were dissected from 2 months old plantlets produced by cultivation the seeds in the farm of GEBRI.

\section{Culture medium:}

Culture medium used in the tissue culture experiments of this study was salt formula of Murashige and Skoog (1962) (MS). The pH value of the used media was adjusted at $5.7 \pm 0.1$ prior to addition of agar $(7 \mathrm{~g} / \mathrm{l})$. The medium was dispensed in jars of $120 \mathrm{ml}$ capacity each with $25 \mathrm{ml}$ medium. The jars were steam sterilized in an autoclave under pressure of $1.2 \mathrm{Kg} / \mathrm{cm}^{2}$ and $121^{\circ} \mathrm{C}$ over a period of 20 minutes. The medium was left for 4 days at room temperature and then used for culture.

\section{This study contained the following experiments: \\ Experiment 1: Establishment of cell lines:}

Callus of Solanum viride was obtained when leaf segments were placed on the previously chosen treatment in part one of this study (MS medium contained $1.5 \mathrm{mg} / \mathrm{l} \mathrm{NAA}$ with $0.5 \mathrm{mg} / \mathrm{l} \mathrm{BA}$ ) (Emara et al. 2008). That callus was suspended in the same treatment but as liquid medium to establish suspension culture. The preparation was left for one week on shaker in light condition. The same treatment was prepared again as solid medium, and the medium was autoclaved at $121 \mathrm{C}^{\circ}$ and $1.2 \mathrm{Kg} / \mathrm{cm}^{2}$ for 20 min., then, the medium was left to get cool but still warm (40 Co) and the previously prepared suspension culture from callus tissue of Solanum viride was added to this medium in flasks $250 \mathrm{ml}$, each flask contained $40 \mathrm{ml}$ solid medium and $10 \mathrm{ml}$ of suspension culture. Then, the mixture was dispensed in 
petry dishes $(5 \mathrm{ml}$ each). The mixture was left in light condition for four weeks. Clusters of callus were obtained from the cells of that mixture, these clusters were taken and subcultured individually in jars contained the same treatment in solid form to increase the amount of these clusters. After 4 weeks the callus was transferred to differentiation medium that was also chosen from part one of this study (MS medium supplemented with $1.0 \mathrm{mg} / \mathrm{l}$ BA) (Emara et al. 2008). At the end of differentiation, 16 shoots of Solanum viride that showed no vitrification were selected and considered as separate clones.

\section{Experiment 2: In vitro growth of Solanum viride plant as affected by number of subculture and clone type:}

Shoots of In vitro obtained clones were transferred to MS medium supplemented with $2.0 \mathrm{mg} / \mathrm{l} \mathrm{BA}$ (the best treatment for direct differentiation according to the results of part one of this study) (Emara et al. 2008). This experiment included five subcultures with interval periods of 4 weeks. Data were recorded at the end of the experiment as shoot number/plantlet, shoot length $(\mathrm{cm})$, leaf number/plantlet and Fresh weight/plantlet $(\mathrm{g})$.

\section{Incubation conditions:}

The cultures were incubated at $25^{\circ} \mathrm{C} \pm 2$ day and night. Light was provided by white fluorescent tubes giving light intensity of 2000 lux at the level of cultures for 16 hours per day.

\section{Experiment 3: Acclimatization of plantlets:}

Plantlets obtained from experiment 2 ( 3 to $5 \mathrm{~cm}$ in length) were cultured on MS basal medium supplemented with $20 \mathrm{~g}$ sucrose $+7 \mathrm{~g}$ agar + $2.0 \mathrm{mg} / \mathrm{l} \mathrm{BA}$ (the same medium of the last experiment (2) with less sucrose). These cultures were incubated in growth room. After 4 weeks, the plantlets were transferred to the greenhouse and planted individually in pots of $6 \mathrm{~cm}$ diameter and filled with mixture of sand and peat moss (1:2, v: v). Plantlets in pots were covered with transparent polyethylene bags (for two weeks) to maintain a high humidity around them. Data were recorded after 1 and 3 months of transplanting as survival percentage, shoot number, leaf number/plantlet and plantlet height $(\mathrm{cm})$.

All experiments were repeated twice and the represented data were averages. Results of these experiments were analyzed by analysis of variance (ANOVA) according to Gomez and Gomez (1984).

\section{Experiment 4: Molecular Analysis:}

Randomly amplified polymorphic DNA (RAPD):

In this study, RAPD was used for the identification of Solanum viride clones according to Lu et al. (1996).

\section{a. DNA Extraction}

Young and fresh leaf samples of clones were collected, all the selected leaves were normal and free from any pathogenic symptoms. All leaf samples were placed in ice box and quickly transported to laboratory. Plant tissues 
Emara, H. A. et al.

were ground under liquid nitrogen to a fine powder, then bulked DNA extraction was performed using DNeasy plant Mini Kit (QIAGEN).

\section{b. Polymerase Chain Reaction (PCR).}

The PCR primers used for RAPDs are listed in Table (1). These primers were selected from the Operon Kit (Operon Biotechnologies, Inc. Germany) with the following sequences:

Table (1): List of the primer names and their nucleotide sequences used in the study for RAPD procedure.

\begin{tabular}{|c|c|c|c|c|c|}
\hline No & Name & Sequence & No & Name & Sequence \\
\hline 11 & OP-CO5 & 5'- GAT GAC CGC C -3" & 5 & OP-O20 & 5- ACA CAC GCT G - 3 \\
\hline 2 & OP-O5 & $55^{\prime-C C C ~ A G T ~ C A C ~ T ~-~ 3 ` ~}$ & 6 & OP-L12 & 5'-GGG CGG TAC T-3 \\
\hline 3 & OP-015 & $55^{\prime}-\mathrm{TGG}$ CGT CCT T - 3 & 7 & OP-MO1 & 5'-GTT GGT GGC T- 3" \\
\hline $\bar{~}$ & OP-01: & 5'- GGT GCA CGT T -3 & 8 & OP-Q18 & 5'- AAG AGA GGG G - 3 \\
\hline
\end{tabular}

Amplification was conducted in $25 \mu \mathrm{l}$ reaction volume containing the following reagents: $2.5 \mu \mathrm{l}$ of dNTPs $(2.5 \mathrm{mM}), 2.5 \mu \mathrm{l}$ of $\mathrm{MgCl}_{2}(2.5 \mathrm{mM})$, and $2.5 \mu \mathrm{l}$ of $10 \mathrm{x}$ buffer, $3.0 \mu \mathrm{l}$ of primer $(10 \mathrm{pmol}), 3.0 \mu \mathrm{l}$ of template DNA (25 $\mathrm{ng} / \mu \mathrm{l}), 1 \mu \mathrm{l}$ of Taq polymerase $(1 \mathrm{U} / \mu \mathrm{l})$ and $10.5 \mu \mathrm{l}$ of sterile $\mathrm{dd} \mathrm{H}_{2} \mathrm{O}$. The DNA amplifications were performed in an automated thermal cycle (model Techno 512) programmed for one cycle at $94^{\circ} \mathrm{C}$ for 4 min followed by 45 cycles for 1 $\mathrm{min}$ at $94^{\circ} \mathrm{C}, 1 \mathrm{~min}$ at $36^{\circ} \mathrm{C}$, and $2 \mathrm{~min}$ at $72^{\circ} \mathrm{C}$. The reaction was finally stored at $72 \circ \mathrm{C}$ for $10 \mathrm{~min}$. Amplified products were size-fractioned (using 1 Kbp ladder marker) by electrophoresis in $1.5 \%$ agarose gel in TBE buffer at $120 \mathrm{~V}$ for $1 \mathrm{~h}$. the bands were visualized by ethidium bromide under UV florescence and photographed.

\section{Data analysis}

The similarity matrices were done using Gel works ID advanced software UVP-England Program. The relationships among genotypes as revealed by dendrogram were done using SPSS windows (Version 10) program. DICE computer package was used to calculate the pairwise difference matrix and plot the phenogram among lines (Yang and Quiros, 1993).

\section{RESULTS AND DISCUSSION}

\section{Experiment 1: Establishment of cell lines:}

Callus of Solanum viride was obtained when leaf segments were placed on the previously chosen treatment in part one of this study (MS contained $1.5 \mathrm{mg} / \mathrm{l} \mathrm{NAA}$ with $0.5 \mathrm{mg} / \mathrm{l} \mathrm{BA}$ ) (Emara et al. 2008). That callus was used to run the experiment of cell line technique. Then, the clusters of callus resulted from cell line experiment were transferred to differentiation medium $(1.0 \mathrm{mg} / \mathrm{l} \mathrm{BA})$ that was determined before in part one of this study (Emara et al. 2008). At the end of differentiation stage, 16 shoots of Solanum viride that showed no vitrification were selected and considered as separate clones during the following experiments. 
In this regard, Ghasemi et al. (2007) reported that, vitrification of regenerates was promoted by increasing the auxin NAA or cytokinin BAP, and $A B A$ in the nutrient medium. Also, Lee et al. (2004) recorded that, the highest regeneration rate was obtained in most shoots from young leaves of Pyrus pyrifolia on a medium based on MS media supplemented with 0.1-1.0 $\mathrm{mg} / \mathrm{L}$ TDZ and 0.1-1.0 mg/L IBA and/or NAA in each cultivar. Physiological differences with BA and TDZ treatments were compared. In the regeneration medium with BA treatments, green foci appeared on the callus surface after 8 days. Then, some adventitious buds were induced on those green foci, resulting in normal shoots. On the other hand, in the medium with TDZ, callus surface turned compact and greenish, and many adventitious buds were formed over the whole area of the callus surface. In some shoots, cultured on the medium with TDZ, there were morphologically abnormal shoots, including vitrified shoots.

\section{Experiment 2: In vitro growth of Solanum viride plant as affected by number of subculture and clone type:}

(a): Effect of subculture number and clone type of Solanum viride on the formation of shoots and leaves in vitro.

In Table (2), regarding the effect of number of subculture on shoot formation, data on the main effect of subculture number reveal that, shoot formation was significantly increased by repeating the subculture up to the third subculture, then, a gradual decrease in shoot number was recorded with the fourth and fifth subcultures. Meanwhile, the third subculture significantly was the best in this concern (Fig. 1).

Data on the main effect of clone type indicate that, the highest shoot number/plantlet was significantly observed with clone 10 (5.01) (Fig. 1) followed by clone 9 (4.85). However, clone 13 showed the lowest shoot number (2.09) compared to the other clones.

As for the interaction, data show that, sporadic records of shoot number were obtained with the different clones during different subcultures. Moreover, the highest shoot number was obtained with clone 9 in the third subculture (6.22) and clone 10 in both second and third subculture (6.11) without significant difference. In the contrary, the lowest shoot number was recorded with the clones 15 and 16 in the first subculture (1.97 and 1.98, respectively)

Concerning the effect of number of subculture on leaf formation in the different clones, in Table (2), data on the main effect of subculture number clearly indicate that, repeating the subculture showed significant positive response in leaf number up to the third subculture, then, negative response was recorded with the fourth and fifth subcultures (Fig. 1). 
Emara, H. A. et al.

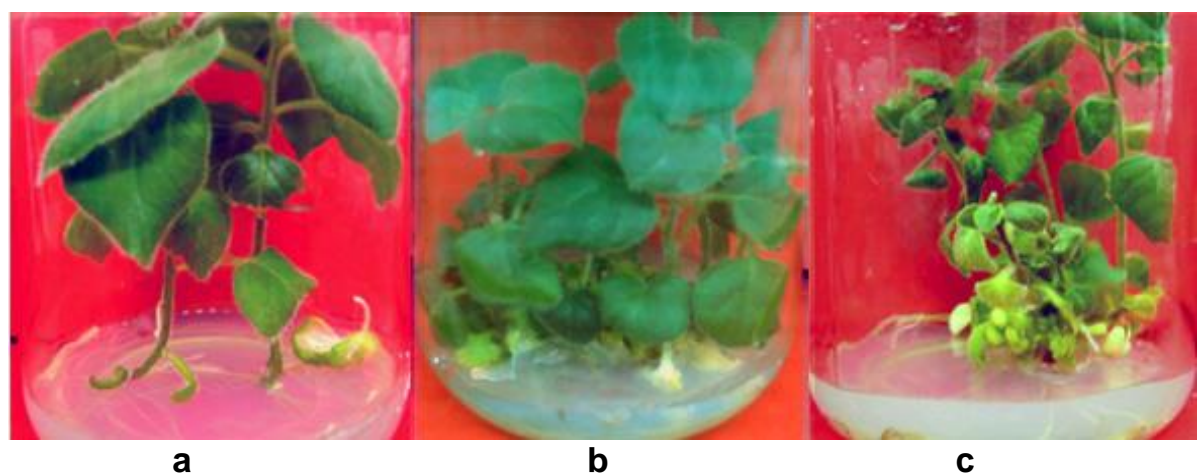

Fig. (1): Effect of number of subculture on the in vitro growth and development of one of Solanum viride clones (clone 10).

a; clone 10 in the first subculture (lowest shoot and leaf number).

b; clone 10 in the third subculture (highest shoot and leaf number).

c; clone 10 in the fifth subculture (negative response in shoot and leaf number).

Data on the main effect of clone type indicate that, clone 10 recorded the best value in leaf formation (47.20) followed by clone 9 (38.30). However, the lowest leaf number was obtained with the clone 16 (21.47).

Referring the interaction, data show that, sporadic leaf numbers were observed with the different clones during the different subcultures. Clone 10 significantly showed the highest leaf number (66.00) in the third subculture followed by clone 9 in the same subculture (57.00). However, clones 15 and 16 contained the lowest leaf number in the most subcultures.

(b): Effect of subculture number and clone type on shoot length $(\mathrm{cm})$ and fresh weight/plantlet $(\mathrm{g})$ of Solanum viride in vitro.

Concerning the effect of the number of subcultures on shoot length in Table (3), data on the main effect of number of subculture indicate that, a significant gradual decrease in shoot length was recorded with repeating the subculture. Moreover, the highest shoot length $(8.71 \mathrm{~cm})$ was observed with the first subculture. The lowest value in that concern $(3.97 \mathrm{~cm})$ was obtained with the fifth subculture.

Data on the main effect of clone type show that, the highest shoot length was obtained with clone $4(8.40 \mathrm{~cm})$ followed by clone $8(8.28 \mathrm{~cm})$ without significant difference. However, clone 1 significantly showed the shortest shoots $(5.31 \mathrm{~cm})$.

Concerning the interaction, sporadic results were obtained with different clones during the different subcultures. The tallest shoots were found in both clone $4(11.10 \mathrm{~cm})$ and clone $8(11.03 \mathrm{~cm})$ in the first 
subculture. In the contrary, the shortest shoots were observed in clone 1 $(2.60 \mathrm{~cm})$ in the fifth subculture.

In the same Table (3), data on the main effect of different subcultures on fresh weight/plantlet $(\mathrm{g})$ reveal that, a significant gradual increase in fresh weight of plantlet was resulted with the gradual increase in number of subculture up to the third subculture that showed the heaviest fresh weight/plantlet $(3.67 \mathrm{~g})$, then, a gradual decrease was recorded with the gradual increase in subculture number.

Data on the main effect of clone type reveal that, clone 10 was the superior one and significantly showed the heaviest fresh weight/plantlet (5.01 $\mathrm{g})$, followed by clone $9(4.21 \mathrm{~g})$. The lowest fresh weight/plantlet $(1.96 \mathrm{~g})$ was significantly obtained with clone 16 .

Concerning the interaction, data in Table (3) show that, the third subculture showed the best records with all clones. Moreover, the heaviest fresh weight/plantlet was significantly found with clone 10 in the third subculture $(6.71 \mathrm{~g})$ followed by the same clone in the fourth subculture $(6.04$ g). The lowest value in that concern $(0.98 \mathrm{~g})$ was significantly observed in the first subculture with clone 16 .

Table (2): Effect of subculture number and clone type of Solanum viride on the formation of shoots and leaves in vitro.

\begin{tabular}{|c|c|c|c|c|c|c|c|c|c|c|c|c|}
\hline \multirow{2}{*}{$\begin{array}{l}\text { Subcultures } \\
\text { clones }\end{array}$} & \multicolumn{6}{|c|}{ Shoot number } & \multicolumn{6}{|c|}{ Leaf number } \\
\hline & 1 & 2 & 3 & 4 & 5 & Means & 1 & 2 & 3 & 4 & 5 & Means \\
\hline 1 & 2.26 & 3.44 & 4.00 & 3.33 & 2.28 & $3.06 \mathrm{e}$ & 18.33 & 26.83 & 44.83 & 27.33 & 17.67 & $27.00 \mathrm{~g}$ \\
\hline 2 & 2.87 & 4.30 & 4.92 & 4.11 & 2.87 & $3.81 \mathrm{c}$ & 21.00 & 32.00 & 50.50 & 32.33 & 20.50 & $7 \mathrm{~d}$ \\
\hline 3 & 2.11 & 2.64 & 3.33 & \begin{tabular}{|l||}
2.44 \\
\end{tabular} & 1.97 & $2.50 \mathrm{~g}$ & 17.83 & 28.17 & 46.00 & 27.67 & 17.17 & $37 \mathrm{~g}$ \\
\hline 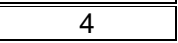 & 2.80 & 3.33 & 3.97 & 3.44 & 3.17 & $3.34 \mathrm{~d}$ & 19.83 & 30.00 & 45.67 & 28.00 & 18.67 & $28.43 \mathrm{f}$ \\
\hline 5 & 2.08 & 2.64 & 3.22 & \begin{tabular}{|l||}
2.30 \\
\end{tabular} & 1.82 & $2.41 \mathrm{~h}$ & 24.33 & 33.50 & 51.50 & 34.33 & 23.17 & $33.37 \mathrm{c}$ \\
\hline 6 & 2.08 & 2.77 & 3.33 & 2.65 & 2.11 & $2.59 \mathrm{gh}$ & 20.83 & 30.67 & 49.00 & 31.00 & 19.33 & $7 \mathrm{e}$ \\
\hline 7 & 2.22 & 2.66 & 3.30 & 2.89 & 2.19 & $2.65 \mathrm{~g}$ & 19.50 & 29.33 & 46.00 & 29.00 & 18.17 & $28.40 \mathrm{f}$ \\
\hline 8 & 2.52 & 3.08 & 3.64 & 3.11 & 2.19 & $2.91 \mathrm{f}$ & 17.67 & 28.67 & 48.00 & 30.33 & 16.50 & $23 f$ \\
\hline 9 & 3.76 & 5.41 & 6.22 & 5.08 & 3.77 & $4.85 \mathrm{~b}$ & 29.50 & 37.83 & 57.00 & 39.00 & 28.17 & \\
\hline 10 & 4.44 & 6.11 & 6.11 & 5.19 & 3.19 & $5.01 \mathrm{a}$ & 37.00 & 48.50 & 66.00 & 49.00 & 35.50 & $20 \mathrm{a}$ \\
\hline 11 & 2.09 & 2.66 & 3.44 & 2.55 & 1.83 & $2.52 \mathrm{gh}$ & 16.83 & 26.00 & 42.33 & 25.00 & 16.67 & $25.37 \mathrm{~h}$ \\
\hline 12 & \begin{tabular}{|l|}
2.44 \\
\end{tabular} & 3.00 & 3.63 & \begin{tabular}{|l||}
2.75 \\
\end{tabular} & 1.83 & $2.80 \mathrm{fg}$ & 14.00 & 20.00 & 36.33 & 19.00 & 12.67 & $22.33 \mathrm{i}$ \\
\hline 13 & 2.52 & 3.41 & 4.08 & 3.11 & 2.30 & $2.09 \mathrm{i}$ & 177.17 & 29.50 & 45.33 & 28.67 & 16.50 & $27.43 \mathrm{~g}$ \\
\hline 14 & 2.93 & 3.52 & 4.28 & 3.22 & 2.55 & $3.30 \mathrm{~d}$ & 16.83 & 26.67 & 43.00 & 26.50 & 15.50 & $25.70 \mathrm{~h}$ \\
\hline 15 & 1.97 & 2.52 & 3.30 & \begin{tabular}{|l||}
2.72 \\
\end{tabular} & 2.11 & $2.52 \mathrm{gh}$ & 13.50 & 24.83 & 40.00 & 24.00 & 12.33 & $22.93 \mathrm{i}$ \\
\hline 16 & 1.98 & 2.41 & 3.33 & 2.55 & 2.07 & $2.47 \mathrm{gh}$ & 12.17 & 23.50 & 38.17 & 21.67 & 11.83 & 21.47 \\
\hline Trean & $2.42 \mathrm{~d}$ & $3.17 b$ & $3.77 \mathrm{a}$ & $2.97 \mathrm{c}$ & $233 d$ & & $18.61 \mathrm{~d}$ & $28.00 \mathrm{~b}$ & $44.10 \mathrm{a}$ & $27.44 \mathrm{c}$ & $18.61 \mathrm{~d}$ & \\
\hline LSD & & $A X$ & $B=0$ & & & & & & $\mathrm{~B}=$ & & & \\
\hline
\end{tabular}

A: Clones

$B_{1}$ : Shoot number

$\mathrm{B}_{2}$ : Leaf number 
Emara, H. A. et al.

Table (3): Effect of subculture number and clone type on plantlet length $(\mathrm{cm})$ and fresh weight/plantlet $(\mathrm{g})$ of Solanum viride in vitro.

\begin{tabular}{|c|c|c|c|c|c|c|c|c|c|c|c|c|}
\hline \multirow{2}{*}{$\begin{array}{l}\text { Subcultures } \\
\text { clones }\end{array}$} & \multicolumn{6}{|c|}{ Shoot length(cm) } & \multicolumn{6}{|c|}{ Fresh weight (g) } \\
\hline & 1 & 2 & 3 & 4 & 5 & Means & 1 & 2 & 3 & 4 & 5 & Means \\
\hline$\overline{11}$ & 7.60 & 6.70 & 5.20 & \begin{tabular}{|l|l|}
4.47 \\
\end{tabular} & 2.60 & $31 \mathrm{j}$ & 1.99 & 3.06 & 3.97 & 3.50 & \begin{tabular}{|l|}
2.01 \\
\end{tabular} & $2.90 \mathrm{f}$ \\
\hline$\overline{2}$ & 4 & 8.80 & 7.23 & 5.57 & 3.90 & $6.99 \mathrm{~d}$ & 2.81 & 3.92 & 4.92 & 4.09 & \begin{tabular}{|l|}
2.61 \\
\end{tabular} & $3.67 \mathrm{c}$ \\
\hline 3 & 97 & 7.93 & 6.87 & 5.90 & 4.20 & $6.77 \mathrm{e}$ & 1.87 & 2.04 & 3.07 & 2.82 & 1.60 & 2.28 \\
\hline 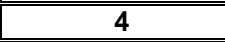 & .10 & 9.90 & 8.90 & 7.30 & 4.80 & $8.40 \mathrm{a}$ & 1.99 & 2.66 & 3.61 & 3.11 & 1.87 & $2.65 \mathrm{~h}$ \\
\hline 5 & 87 & 7.87 & 5.30 & 4.50 & 3.80 & $6.07 \mathrm{~h}$ & 1.20 & 2.10 & 3.04 & 2.54 & 1.32 & 2.041 \\
\hline 6 & 03 & 7.93 & 6.30 & 5.70 & 3.87 & $6.57 \mathrm{f}$ & 1.70 & 2.18 & 3.04 & 2.61 & 1.45 & $2.19 \mathrm{k}$ \\
\hline 7 & 7.73 & 6.77 & 5.30 & 5.10 & 3.60 & $5.70 \mathrm{i}$ & 1.41 & 2.20 & 3.05 & 2.52 & 1.23 & $2.08 \mathrm{I}$ \\
\hline 8 & 11.03 & 9.93 & 8.30 & 7.23 & 4.90 & $8.28 \mathrm{a}$ & 2.17 & 2.92 & 3.73 & 3.20 & 2.05 & $2.81 \mathrm{~g}$ \\
\hline 9 & 9.60 & 8.73 & 7.33 & 5.90 & 4.60 & $7.23 \mathrm{c}$ & 2.94 & 4.33 & 5.38 & 5.00 & 3.40 & $4.21 \mathrm{~b}$ \\
\hline$\overline{10}$ & .13 & 8.00 & 6.40 & 5.13 & 4.37 & $6.61 \mathrm{f}$ & 3.00 & 5.00 & 6.71 & 6.04 & 4.29 & $5.01 \mathrm{a}$ \\
\hline 11 & .67 & 7.60 & 5.87 & 5.10 & 3.90 & $6.23 \mathrm{~g}$ & 1.84 & 2.61 & 3.48 & 2.98 & 1.82 & $2.54 \mathrm{i}$ \\
\hline 12 & 9.00 & \begin{tabular}{|l|l|}
7.87 \\
\end{tabular} & 6.27 & 5.60 & 4.17 & $6.71 \mathrm{ef}$ & 2.00 & 2.84 & 3.83 & 3.39 & 2.00 & $2.86 \mathrm{fg}$ \\
\hline 13 & 9.77 & 9.07 & 7.70 & 6.23 & 4.47 & $7.45 \mathrm{~b}$ & 2.42 & 3.24 & 4.04 & 3.66 & 2.23 & $3.12 \mathrm{e}$ \\
\hline 14 & 8.70 & 7.90 & 6.30 & 4.87 & 3.60 & $6.27 \mathrm{~g}$ & 2.68 & 3.74 & 4.53 & 3.99 & \begin{tabular}{|l|}
2.87 \\
\end{tabular} & $3.56 \mathrm{~d}$ \\
\hline 15 & 9.57 & 8.67 & 7.30 & 5.80 & 4.17 & $7.10 \mathrm{c}$ & 1.03 & 2.04 & 3.08 & 2.67 & 1.48 & 2.061 \\
\hline 16 & 9.83 & 8.963 & 7.70 & (6.23 & 4.50 & $7.44 \mathrm{~b}$ & 0.98 & 1.98 & 3.00 & 2.48 & 1.35 & $1.96 \mathrm{~m}$ \\
\hline & $8.71 \mathrm{a}$ & $7.80 \mathrm{~b}$ & $6.37 \mathrm{c}$ & $5.25 \mathrm{~d}$ & $3.97 \mathrm{e}$ & & $1.88 \mathrm{e}$ & $2.75 \mathrm{c}$ & $3.67 \mathrm{a}$ & $3.13 b$ & $2.07 \mathrm{~d}$ & \\
\hline LSD & & $\mathbf{A X}$ & $\mathbf{B}=\mathbf{0}$. & & & & & & $B=0$ & & & \\
\hline
\end{tabular}

\section{Experiment 3: Acclimatization of plantlets:}

Survival percentage and some growth parameters (shoot and leaf number/plantlet and plantlet length) of Solanum viride clones were recorded after 1 and 3 months from transplanting to the greenhouse. In Table (4), data on the effect of period and condition of acclimatization on survival percentage of different clones indicate that, the survival percentage was the same after 1 and 3 months from transferring to the greenhouse. That percentage was between $65.33 \%$ and $95.00 \%$ either after one or three months. The highest survival percentage $(95.00 \%)$ was recorded with clone 11 followed by clone 10 (92.33) without significant difference. The lowest percentage $(65.33 \%)$ was obtained with clone 16.

Represented data in Table (4) on shoot number show that, the highest shoot number was obtained with clone 10 after one (2.67) or three months (10.67). However, clone 16 showed the lowest shoot number after either one (1.0) or three months (2.33), (Fig. 2). Although some other clones significantly observed similar results to clone 10 after one month only, but clone 7 only showed similar results to clone 10 after 3 months.

concerning the effect of acclimatization on plantlet length in the different clones, plants of clone 9 and clone 10 were recorded as the tallest plants after one or three months without significant difference. However, the shortest plants were observed in clone 1 after one $(7.60 \mathrm{~cm})$ and three months $(28.67$ $\mathrm{cm}$ ), (Fig. 2).

In the same Table (4), data of leaf number reveal that, the highest leaf number was recorded with clone 10 followed by clone 9 after one or three 
months, on the other hand, clone 16 significantly showed the lowest record in that concern after one (7.33) and three months (22.33), (Fig. 2).

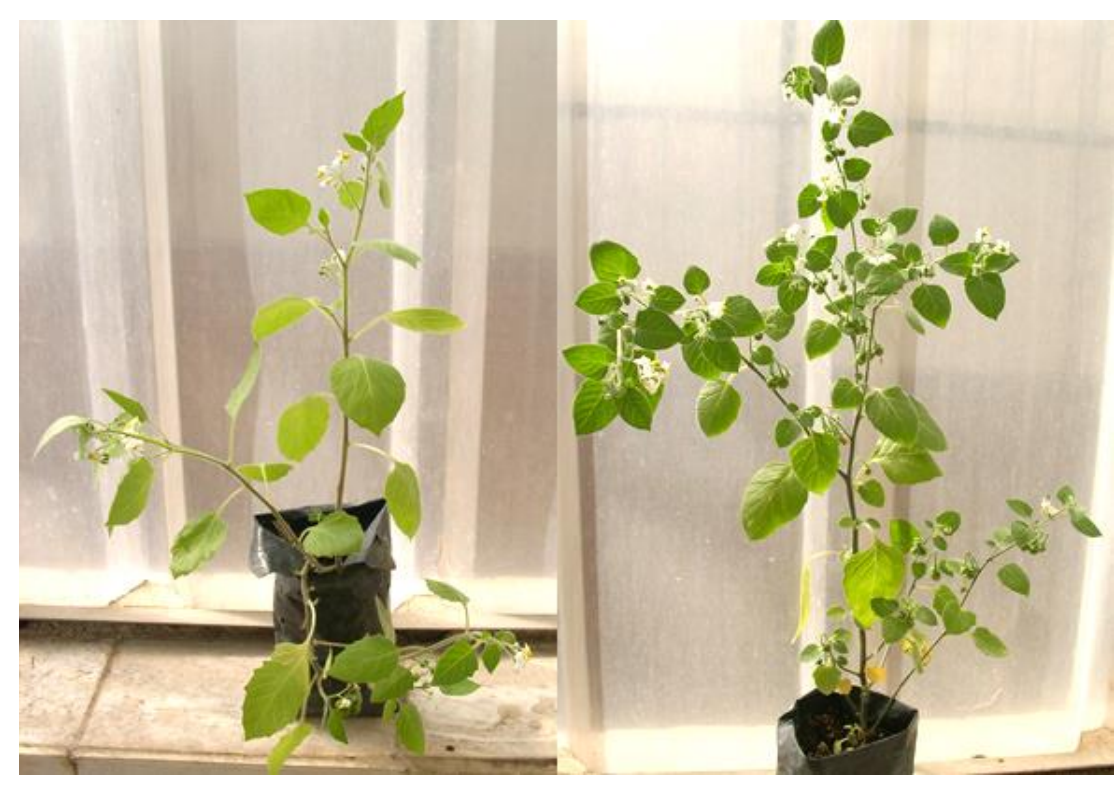

a

b

Fig. (2): Different clones of Solanum viride plant grown in soil mixture of peatmoss and sand $(2: 1, v: v)$ for three months a; clone 16 b; clone 10

In that concern, Kannan, et al. (2006) recorded that, the rooted plantlets of $S$. nigrum were successfully established in soil. Also, Jawahar, et al. (2004) found that, S. nigrum plantlets were successfully hardened and transferred to the field. Moreover, Manjula and Nair, (2002) reported that, the best shoot regeneration from Solanum aculeatissimum explants was achieved from IAA-derived leaf callus when transferred to MS medium containing IAA $(0.5 \mathrm{mg} / \mathrm{l})$ and kinetin $(4 \mathrm{mg} / \mathrm{l})$, which gave the maximum number of shoots (38+or-0.6) per gram callus. Microshoots were rooted on MS medium containing IBA $(1 \mathrm{mg} / \mathrm{l})$. The regenerated plantlets were successfully established in soil with $90 \%$ survival. 
Emara, H. A. et al.

Table (4): Survival percentage and vegetative growth as affecting by acclimatization of Solanum viride clones in greenhouse. After months

According to all results of this study that showed many morphological differences in the selected clones between each other and the mother plant, DNA fingerprint was carried out to ensure and justify these differences and the results were as following:

\section{Experiment 4: Molecular Analysis:}

Randomly Amplified Polymorphic DNA (RAPD) markers:

Data of the amplified fragments using those eight primers for the 16 clones succeeded in amplifying DNA fragments (Fig., 3). Polymorphism levels differed from one primer to another. Primers OP-O15 and OP-O19 exhibited low polymorphism $(45.5 \%)$. On the other hand, primers OP-CO5 (92.3\%), OP-O5 (63.6\%), OP-O20 (76.9\%), OP-L12 (92.8\%), OP-MO1 (75.0 $\%)$, OP-Q18 (100\%), exhibited high levels of polymorphism which is useful in

\begin{tabular}{|c|c|c|c|c|c|c|c|c|}
\hline \multirow[b]{2}{*}{ clones } & \multirow[b]{2}{*}{ Survival \% | } & \multicolumn{3}{|c|}{ After 1 month } & \multicolumn{4}{|c|}{ After 3 months } \\
\hline & & $\begin{array}{l}\text { Shoot } \\
\text { number }\end{array}$ & $\begin{array}{c}\text { plantlet } \\
\text { height } \\
\text { (cm) }\end{array}$ & $\begin{array}{c}\text { Leaf } \\
\text { number }\end{array}$ & Survival \% & $\begin{array}{c}\text { Shoot } \\
\text { number }\end{array}$ & $\begin{array}{c}\text { plantlet } \\
\text { height } \\
\text { (cm) }\end{array}$ & $\begin{array}{c}\text { Leaf } \\
\text { number }\end{array}$ \\
\hline 1 & $71.67 \mathrm{~cd}$ & $1.67 \mathrm{bc}$ & $7.60 \mathrm{~g}$ & $14.33 \mathrm{~d}$ & $71.67 \mathrm{~cd}$ & $8.00 \mathrm{c}$ & $28.67 \mathrm{~g}$ & $78.00 \mathrm{~d}$ \\
\hline 2 & $86.67 \mathrm{~b}$ & $2.33 \mathrm{ab}$ & $13.40 \mathrm{de}$ & $15.00 \mathrm{~d}$ & $86.67 \mathrm{~b}$ & $8.00 \mathrm{c}$ & $51.33 \mathrm{de}$ & $79.33 \mathrm{~d}$ \\
\hline 3 & $85.00 \mathrm{~b}$ & $1.83 \mathrm{~b}$ & $14.10 \mathrm{~d}$ & $16.33 \mathrm{c}$ & $85.00 \mathrm{~b}$ & $8.67 \mathrm{bc}$ & $40.67 \mathrm{f}$ & $90.00 \mathrm{c}$ \\
\hline 4 & $74.40 \mathrm{~cd}$ & $1.33 \mathrm{bc}$ & $17.17 \mathrm{c}$ & $8.67 \mathrm{f}$ & $74.40 \mathrm{~cd}$ & $4.67 \mathrm{e}$ & $49.33 \mathrm{e}$ & $46.67 \mathrm{~h}$ \\
\hline 5 & $78.33 \mathrm{c}$ & $1.50 \mathrm{bc}$ & $9.10 \mathrm{f}$ & $9.33 \mathrm{f}$ & $78.33 \mathrm{c}$ & $5.33 \mathrm{de}$ & $29.33 \mathrm{~g}$ & $63.00 \mathrm{~g}$ \\
\hline 6 & $72.33 \mathrm{~cd}$ & $1.83 \mathrm{~b}$ & $18.93 \mathrm{~b}$ & $16.33 \mathrm{c}$ & $72.33 \mathrm{~cd}$ & $7.33 \mathrm{c}$ & $48.67 \mathrm{e}$ & $80.33 \mathrm{~d}$ \\
\hline 7 & $88.33 \mathrm{a}$ & $1.50 \mathrm{bc}$ & $17.30 \mathrm{c}$ & $17.67 \mathrm{~b}$ & $88.33 \mathrm{a}$ & $9.67 \mathrm{ab}$ & $49.33 \mathrm{e}$ & $95.33 \mathrm{~b}$ \\
\hline 8 & $78.87 \mathrm{bc}$ & $2.00 \mathrm{a}$ & $18.43 \mathrm{bc}$ & $15.67 \mathrm{~cd}$ & $78.87 \mathrm{bc}$ & $6.00 \mathrm{~d}$ & $59.33 \mathrm{bc}$ & $78.67 \mathrm{~d}$ \\
\hline 9 & $83.33 \mathrm{bc}$ & $2.50 \mathrm{a}$ & $20.80 \mathrm{a}$ & $18.67 \mathrm{a}$ & $83.33 \mathrm{bc}$ & $9.17 \mathrm{~b}$ & $68.33 \mathrm{a}$ & $98.00 \mathrm{ab}$ \\
\hline 10 & $92.33 \mathrm{ab}$ & $2.67 \mathrm{a}$ & $19.87 \mathrm{ab}$ & $19.33 \mathrm{a}$ & $92.33 \mathrm{ab}$ & $10.67 \mathrm{a}$ & $61.67 \mathrm{~b}$ & $103.33 \mathrm{a}$ \\
\hline 11 & $95.00 \mathrm{a}$ & $1.83 \mathrm{~b}$ & $13.07 \mathrm{de}$ & $9.67 \mathrm{f}$ & $95.00 \mathrm{a}$ & $6.00 \mathrm{~d}$ & $58.67 \mathrm{c}$ & $70.67 \mathrm{f}$ \\
\hline 12 & $76.67 \mathrm{c}$ & $1.67 \mathrm{bc}$ & $13.33 \mathrm{de}$ & $16.33 \mathrm{c}$ & $76.67 \mathrm{c}$ & $9.33 \mathrm{~b}$ & $58.33 \mathrm{c}$ & $90.33 \mathrm{c}$ \\
\hline 13 & $85.00 \mathrm{bc}$ & $2.50 \mathrm{a}$ & $18.57 \mathrm{~b}$ & $18.00 \mathrm{~b}$ & $85.00 \mathrm{bc}$ & $9.17 \mathrm{bc}$ & $66.67 \mathrm{a}$ & $92.33 \mathrm{bc}$ \\
\hline 14 & $82.21 \mathrm{bc}$ & $2.00 \mathrm{ab}$ & $18.47 \mathrm{bc}$ & $15.67 \mathrm{~cd}$ & $82.21 \mathrm{bc}$ & $8.17 \mathrm{bc}$ & $59.67 \mathrm{bc}$ & $80.00 \mathrm{~d}$ \\
\hline 15 & $68.67 \mathrm{~d}$ & $2.33 \mathrm{ab}$ & $12.63 \mathrm{e}$ & $13.67 \mathrm{e}$ & $68.67 \mathrm{~d}$ & $8.33 \mathrm{bc}$ & $40.00 \mathrm{f}$ & $75.00 \mathrm{e}$ \\
\hline
\end{tabular}

Solanum viride identification. The number of total amplified fragments (TAF), and Polymorphic bands (PB) for each primer, Amplified fragments (AF) and

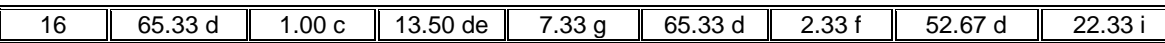
Specific markers (SM) for each clone using the 8 primers are shown in Table (5). 
J. Agric. Sci. Mansoura Univ., 33 (3), March, 2008

Fig (3): Amplified fragments obtained from the DNA of Solanum viride (mother plant and sixteen clones). 
Emara, H. A. et al.

Table (5): Number of amplified fragments and specific markers of the Solanum viride (mother plant and 16 clones) based on RAPD-PCR analysis using eight primers.

\begin{tabular}{|c|c|c|c|c|c|c|c|c|c|c|}
\hline \multicolumn{2}{|c|}{ Primer No. } & \begin{tabular}{|c|} 
OPC0- \\
5
\end{tabular} & $\begin{array}{c}\text { OP0- } \\
5\end{array}$ & $\begin{array}{c}\text { OP0- } \\
15\end{array}$ & $\begin{array}{c}\text { OP0- } \\
19\end{array}$ & $\begin{array}{c}\text { OP0- } \\
20\end{array}$ & $\begin{array}{c}\text { OPL- } \\
12\end{array}$ & \begin{tabular}{|c|} 
OPMO \\
-1 \\
\end{tabular} & $\begin{array}{c}\text { OPQ- } \\
18\end{array}$ & Total \\
\hline \multicolumn{2}{|c|}{ TAF } & 13 & 11 & 11 & 11 & 13 & 14 & 12 & 17 & 102 \\
\hline \multicolumn{2}{|c|}{ PB } & $\overline{12}$ & $\overline{77}$ & $\overline{\mid c 5}$ & $\overline{\mid c 5}$ & $\overline{|c|}$ & 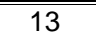 & $\overline{99}$ & $\overline{|c|}$ & $\overline{\mid 78}$ \\
\hline \multicolumn{2}{|c|}{ PB \% } & 92.3 & 63.6 & 45.5 & 45.5 & 76.9 & 92.8 & 75.0 & 100 & 76.5 \\
\hline \multirow{2}{*}{ M } & AF & 3 & 6 & 8 & 8 & 7 & 3 & 3 & 10 & 48 \\
\hline & SM & $1(-)$ & 0 & 0 & 0 & 0 & $1(+)$ & 0 & $2(+)$ & 4 \\
\hline \multirow{2}{*}{1} & AF & 5 & 7 & 8 & 8 & 5 & 7 & 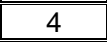 & 8 & 52 \\
\hline & SM & 0 & 0 & 0 & 0 & 0 & 0 & 0 & 0 & 0 \\
\hline \multirow{2}{*}{2} & AF & $\bar{~} 4$ & 8 & 8 & 8 & 6 & 6 & $\overline{3}$ & 8 & 51 \\
\hline & SM & 0 & 0 & 0 & 0 & 0 & 0 & 0 & 0 & 0 \\
\hline \multirow{2}{*}{3} & AF & 7 & 8 & 8 & 8 & 6 & 7 & 3 & 10 & 57 \\
\hline & SM & 0 & 0 & 0 & 0 & 0 & $1(+)$ & 0 & 0 & 1 \\
\hline \multirow{2}{*}{4} & AF & 8 & 8 & 7 & 8 & 9 & 6 & 4 & 10 & 60 \\
\hline & SM & 0 & 0 & 0 & 0 & 0 & 0 & 0 & 0 & 0 \\
\hline \multirow{2}{*}{5} & AF & 5 & 9 & 8 & 8 & 8 & 9 & 6 & 9 & 62 \\
\hline & SM & 0 & 0 & 0 & 0 & 0 & 0 & 0 & 0 & 0 \\
\hline \multirow{2}{*}{6} & AF & 8 & 9 & 8 & 8 & 8 & 9 & 7 & 3 & 60 \\
\hline & SM & 0 & 0 & 0 & 0 & 0 & 0 & 0 & $2(-)$ & 2 \\
\hline \multirow{2}{*}{7} & AF & 8 & 9 & 8 & 8 & 8 & 9 & 9 & 6 & 65 \\
\hline & SM & 0 & 0 & 0 & 0 & 0 & 0 & $1(+)$ & 0 & 1 \\
\hline \multirow{2}{*}{8} & AF & 6 & 9 & 8 & 8 & 7 & 8 & 7 & 5 & 68 \\
\hline & SM & 0 & 0 & 0 & 0 & 0 & 0 & 0 & 0 & 0 \\
\hline \multirow{2}{*}{9} & AF & 5 & 7 & 7 & 8 & 8 & 5 & 6 & 6 & 54 \\
\hline & SM & 0 & 0 & 0 & 0 & 0 & 0 & 0 & $1(+)$ & 1 \\
\hline \multirow{2}{*}{10} & AF & 3 & 6 & 7 & 9 & 7 & 6 & 6 & 3 & 47 \\
\hline & SM & 0 & 0 & 0 & 0 & 0 & 0 & 0 & 0 & 0 \\
\hline \multirow{2}{*}{11} & AF & 3 & 6 & 7 & 8 & 7 & 6 & 8 & 6 & 51 \\
\hline & SM & 0 & 0 & 0 & 0 & 0 & 0 & $\overline{0}$ & $11(+)$ & 1 \\
\hline \multirow{2}{*}{12} & AF & 6 & 6 & 8 & 10 & 8 & 7 & 8 & 4 & 57 \\
\hline & SM & 0 & 0 & 0 & $11(+)$ & 0 & 0 & 0 & 0 & 1 \\
\hline \multirow{2}{*}{13} & $\mathbf{A F}$ & 6 & 6 & 8 & 7 & 7 & 7 & 8 & 4 & 53 \\
\hline & SM & 0 & 0 & 0 & 0 & 0 & 0 & 0 & 0 & 0 \\
\hline \multirow{2}{*}{14} & AF & 3 & 6 & 8 & 8 & 8 & 7 & 8 & 4 & 52 \\
\hline & SM & 0 & 0 & 0 & 0 & (1(+) & 0 & 0 & 0 & 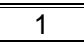 \\
\hline \multirow{2}{*}{15} & AF & 4 & 6 & 8 & 8 & 7 & 4 & 8 & 3 & 47 \\
\hline & SM & 0 & 0 & 0 & 0 & 0 & 11(-) & 0 & 0 & 1 \\
\hline \multirow{2}{*}{16} & AF & 6 & 6 & 8 & 8 & 7 & 5 & 8 & 3 & 52 \\
\hline & SM & 0 & 0 & 0 & 0 & 0 & 0 & 0 & 0 & 0 \\
\hline & $\bar{~} 1$ & 0 & 0 & $\overline{c 1}$ & $\bar{~} 1$ & 3 & $\overline{c 1}$ & 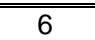 & \\
\hline
\end{tabular}

TAF: The number of total amplified fragments.

PB: Polymorphic bands for each primer.

AF: Amplified fragments.

SM: Specific markers. 
There were some specific fragments discriminated each clone from the others as follows, Primer OP-CO5 showed specific fragment as a negative marker for mother plant, Primer OPO-19 showed a specific fragment as a positive marker for clone 12, primer OP-O20 showed specific fragments as positive marker for clone14, Primer OP-L12 showed three specific fragments, two of them as a positive marker for clone 3 and the mother plant and the other specific fragment as negative marker for clone 15. Primer OP-MO1 showed a specific fragment as a positive marker for clone 7 and Primer OPQ18 showed six specific fragments, four of them as positive markers for clones 9,10 and the mother plant, and the others were negative markers for clone 6 .

\section{Phylogenetic Relationships}

Genetic similarities and phylogenetic relationships between the 16 clones and the mother plant based on RAPD-PCR markers were determined by using computer program SPSS (ver. 10). The phylogenetic dendrogram based on the RAPD-PCR markers (Fig., 4) separated the 16 clones and the mother plant into two major groups. The first group included the mother plant and clones 1,2,3 and 4, while the second group divided into two subgroups, the first contained clones 5,6,7 and 8, the second included clones $9,10,11,12,13,14,15$, and line 16 .

The lowest similarity value $(0.0)$ was scored between the mother plant and clone 7 , while the highest similarity value (1.0) was scored between clone 13 and clone 14 and between clone 15 and clone 16. Table (6).

In this regard, Singh, et al. (2006) used Random Amplified Polymorphic DNA (RAPD) technique as a tool for assessing genetic diversity and species relationships among 28 accessions of aubergine representing five species (Solanum melongena, S. incanum, S. viarum, S. surattense and S. nigrum), and concluded that, genetically distinct genotypes identified using RAPD markers could be potential sources of germplasm improvement. Also, Szczerbakowa, et al. (2003) showed that, thirty-two somatic hybrids were identified by their intermediate morphology (leaves of nigrum type and flowers of tuberosum type) and verified by flow cytometry and random amplified polymorphic DNA (RAPD) patterns. The RAPD analysis of nuclear DNA confirmed the hybrid nature of 29 clones. Flow cytometry revealed a wide range of ploidy in the generated hybrids, from nearly the tetra- to decaploid level. Most of the hybrid clones were stable in vitro, grew vigorously in soil, and set flowers and parthenocarpic berries. Baird, et al. (1992) reported that, randomly amplified polymorphic DNA (RAPD) techniques have recently been used to assess the genomic variation at the molecular level of plants regenerated from potato protoplasts and fusion products. 
Emara, H. A. et al.

Fig (4): Dendrogram using Average Linkage (Between Groups) Rescaled Distance Cluster Combine

Table (6): Percentage of similarity indices among Solanum viride plant and its sixteen clones based on RAPD analysis.

\begin{tabular}{|l|l|l|l|l|l|l|l|l|l|l|l|l|l|l|l|l|l||}
\hline & $\mathrm{M}$ & 1 & 2 & 3 & 4 & 5 & 6 & 7 & 8 & 9 & 10 & 11 & 12 & 13 & 14 & 15 \\
\hline $\mathbf{M}$ & & & & & & & & & & & & & & & & \\
\hline $\mathbf{1}$ & 0.80 & & & & & & & & & & & & & & & \\
\hline $\mathbf{2}$ & 0.72 & 0.95 & & & & & & & & & & & & & & \\
\hline \hline $\mathbf{3}$ & 0.65 & 0.72 & 0.85 & & & & & & & & & & & & & \\
\hline \hline $\mathbf{4}$ & 0.52 & 0.55 & 0.67 & 0.95 & & & & & & & & & & & & \\
\hline $\mathbf{5}$ & 0.27 & 0.40 & 0.62 & 0.70 & 0.77 & & & & & & & & & & & \\
\hline \hline $\mathbf{6}$ & 0.12 & 0.30 & 0.47 & 0.50 & 0.52 & 0.87 & & & & & & & & & & \\
\hline $\mathbf{7}$ & 0.00 & 0.17 & 0.35 & 0.42 & 0.45 & 0.70 & 0.85 & & & & & & & & & \\
\hline $\mathbf{8}$ & 0.12 & 0.25 & 0.37 & 0.40 & 0.47 & 0.62 & 0.72 & 0.80 & & & & & & & & \\
\hline $\mathbf{9}$ & 0.37 & 0.45 & 0.47 & 0.35 & 0.37 & 0.37 & 0.47 & 0.55 & 0.77 & & & & & & & \\
\hline $\mathbf{1 0}$ & 0.45 & 0.47 & 0.50 & 0.37 & 0.35 & 0.45 & 0.45 & 0.47 & 0.70 & 0.85 & & & & & & \\
\hline $\mathbf{1 1}$ & 0.30 & 0.32 & 0.40 & 0.27 & 0.25 & 0.40 & 0.35 & 0.52 & 0.65 & 0.75 & 0.87 & & & & & \\
\hline $\mathbf{1 2}$ & 0.15 & 0.32 & 0.25 & 0.17 & 0.25 & 0.30 & 0.30 & 0.47 & 0.60 & 0.65 & 0.72 & 0.82 & & & & \\
\hline $\mathbf{1 3}$ & 0.25 & 0.37 & 0.30 & 0.22 & 0.25 & 0.30 & 0.35 & 0.52 & 0.60 & 0.70 & 0.72 & 0.82 & 0.97 & & & \\
\hline $\mathbf{1 4}$ & 0.32 & 0.40 & 0.37 & 0.25 & 0.22 & 0.37 & 0.27 & 0.45 & 0.47 & 0.57 & 0.70 & 0.85 & 0.90 & 1.00 & & \\
\hline $\mathbf{1 5}$ & 0.30 & 0.32 & 0.35 & 0.17 & 0.20 & 0.30 & 0.30 & 0.42 & 0.50 & 0.70 & 0.77 & 0.82 & 0.82 & 0.97 & 0.95 & \\
\hline $\mathbf{1 6}$ & 0.22 & 0.30 & 0.27 & 0.15 & 0.17 & 0.32 & 0.32 & 0.35 & 0.52 & 0.62 & 0.65 & 0.80 & 0.85 & 0.95 & 0.82 & 1.00 \\
\hline \hline
\end{tabular}




\section{REFERENCES}

Assareh, M. H. and M. J. Hennerty (1997): Reduction of shoot vitrification in Eucalyptus camaldulensis using a new antivitrification agent (EM2) and agar concentrations. Crop Science, Horticulture and Forestry; 15: 214219.

Baird, E. S.; R. D. Cooper; M. Waugh; M. Maine and W. Powell (1992): Molecular characterization of inter-specific somatic hybrids of potato using randomly amplified polymorphic DNA (RAPD) markers. Molecular and General Genetics. 233: 469-475.

Emara, H. A.; I. A. Ibrahim; M. H. EL-Massry and A. A. Dahab (2008): Biotechnological Studies on Solanum viride Plant. a- In vitro propagation of Solanum viride plant through tissue culture technique. Journal of Agricultural Sciences, Mansoura Univ., Vol. ,No. , pp:

Ghasemi B. K.; G. I. Karlov and A. Ahmadikhah (2007): Effects of genotype, explant type and nutrient medium components on canola (Brassica napus L.) shoot in vitro organogenesis. African Journal of Biotechnology, Vol. 6, No. 7: 861-867.

Gomez, K. A. and A. A. Gomez (1984): Statistical Procedures for the Agricultural Researches. John Wiley and Son, Inc. New York.

Han, S. T. (1998): Medicinal Plants in the South Pacific. Western Pacific: Series No. (19): 179.

Jawahar, M.; T. S. M. Shibu; S. V. Anand; M. Jeyasseelan; A. V. P. Karthikeyan and A. K. Mohan (2004): In vitro regeneration of a medicinal plant Solanum nigrum L. from stem explants. Advances-inPlant-Sciences; 17 (2): 361-365.

Kannan, T. M. S.; S. M. Nagarajan and S. Kulothungan (2006): Micropropagation of Solanum nigrum L. - a medicinal herb. PlantArchives; 6 (1): 97-99.

Lee, C. H.; S. B. Kim; D. H. Han; C. S. Kim; Y. M. Noh; S. J. Ban; D. W. Lee and G. P. Lee (2004): Shoot organogenesis from leaf explants in Japanese pear (Pyrus pyrifolia). Acta Horticulturae ; (653): 215-218.

Lu, Z. X.; G. L. Reighard; W. V. Baird; A. G. Abbott and S. Rajapakse (1996): Identification of peach rootstock cultivars by RAPD markers. HortScience, 31: 127-129.

Manjula, S. and G. M. Nair (2002): High frequency plantlet regeneration via organogenesis in Solanum aculeatissimum Jacq. and possible exploitation of solasodine. Journal-of-Plant-Biology; 29 (1): 23-27.

Mohamed, Y. Y.; T. L. Davenport, W. E. Splittstoesser, and R. E. Litz. (1992): Abnormal stomata in vitrified plants formed in vitro. Proc. Fla. State, Hort. Soc. 105: 210-212.

Murashige, T. and F. Skoog (1962): A revised medium for rapid growth and bioassays with tobacco tissue culture. Physiol. Plantarum; 15: 473-497.

Nada, C. N.; Z. S. Mihajlo and Z. M. Dejan (2005): Liquid-liquid systems for acid hydrolysis of glycoalkaloids from Solanum tuberosum L. tuber sprouts and solanidine extraction. Med. Sci. Monit.; 11 (7): 200-205. 


\section{Emara, H. A. et al.}

Singh, A. K.; S. Major; A. K. Singh; S. Rakesh; K. Sanjeev and G. Kalloo (2006): Genetic diversity within the genus Solanum (Solanaceae) as revealed by RAPD markers. Current-Science; 90 (5): 711-716

Szczerbakowa, A.; U. Maciejewska ; G. E. Zimnoch and B. Wielgat (2003): Somatic hybrids of Solanum nigrum $(+) S$. tuberosum: morphological assessment and verification of hybridity. Plant Cell Reports; 21 (6): 577-584.

Yang, X. and C. F. Quiros (1993): Identification and classification of celery cultivars with RAPD markers. Theoritical and Appleid Genetics, 86: 205-212.

$$
\begin{aligned}
& \text { دراسات بيوتكنولوجية على نبات السولانم فيرايد: }
\end{aligned}
$$

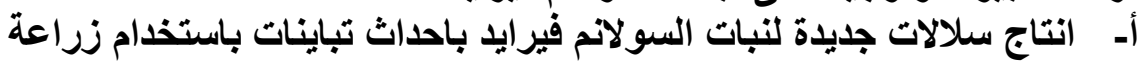

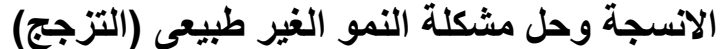

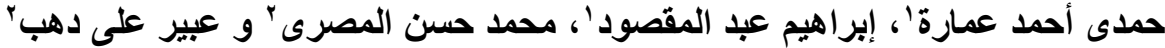

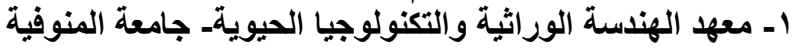

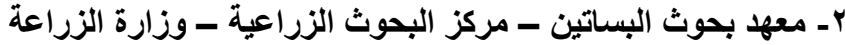

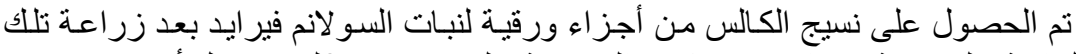

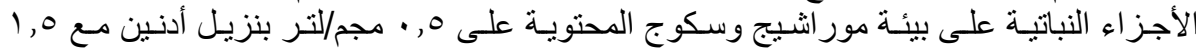

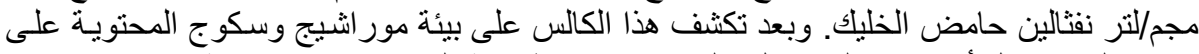

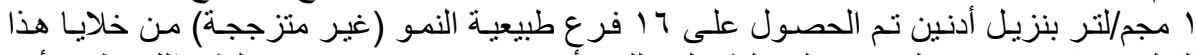

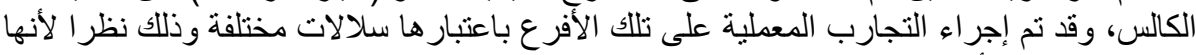

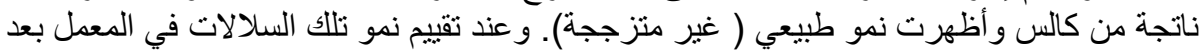

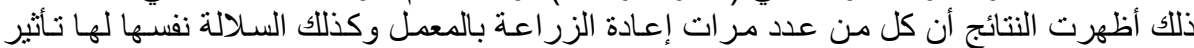

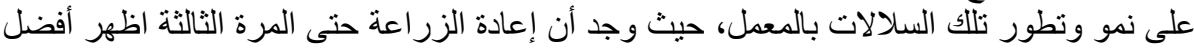

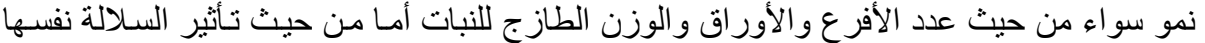

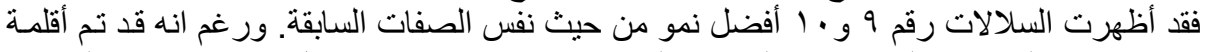

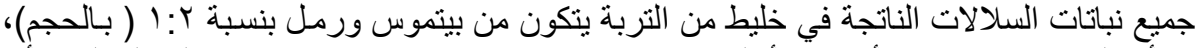

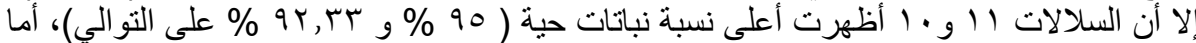

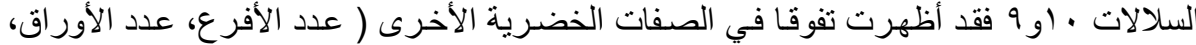

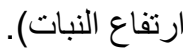

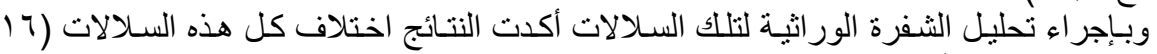

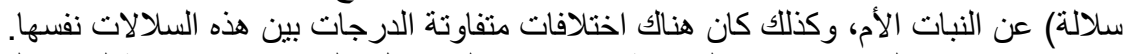

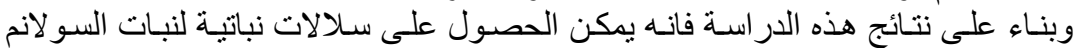

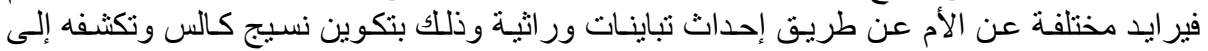
نموات خضرية. 